\title{
AUTONOMY AND LIBERTY IN AUGUSTINE AND KANT: THE PREDOMINANCE OF THE FORMALISM IN THE CONCEPT OF WILL
}

\author{
AUTONOMIA E LIBERDADE EM AGOSTINHO E KANT: A PREDOMINÂNCIA DO FORMALISMO \\ NO CONCEITO DE VONTADE
}

Marcone Costa Cerqueira*

\begin{abstract}
The aims that animates this research is to demonstrate how the theoretical construction of the aspects of the foundations of the will, perceived in a final configuration in Kantian thought, requires by way of searching for an autonomous instance of desire, disengaged of the heteronomy of the contingent, which appears first in the Christian Middle Ages construction, establishing the predominance of the formal aspect of the action over its material aspect in the ethical-political field in the West. The theoretical basis of our hypothesis is guided by the relationship between the formal (intentionality - want) and concrete (materiality - act) of political action. Such a configuration will be demonstrated from construction of a theory of the will, which has arisen within the medieval Christianity, expanded and refined by several western authors, and your more formatting done in modern thought, in which the rational construction of formalism is your complete maturation in Kantian construct.

KEYWORDS: I. Kant. Augustine. Theory of Will. Liberty. Autonomy.
\end{abstract}

\section{RESUMO}

O objetivo que anima este trabalho de pesquisa consiste em demonstrar como a construção teórica dos aspectos fundantes da vontade, percebida em sua configuração final no pensamento kantiano, enseja-se por vias da busca de uma instância autônoma do querer, despregada da heteronomia do contingente, que surge primeiro na construção cristã do medievo, estabelecendo a predominância do formal sobre o material da ação no campo éticopolítico no Ocidente. A base teórica de nossa hipótese se guia pela relação entre o formal (intencionalidade - querer) e o concreto (materialidade - agir) da ação política. Tal configuração será demonstrada a partir da construção de uma teoria da vontade, surgida no seio da cristandade medieval, ampliada e sofisticada por inúmeros autores ocidentais, e que encontra sua formatação mais acabada no pensamento moderno, no qual a construção racional de seu formalismo encontra completa maturação no construto kantiano.

PALAVRAS-CHAVE: I. Kant. Agostinho. Teoria da Vontade. Liberdade. Autonomia.

\footnotetext{
*Doutorando em filosofia pela Universidade Federal de Santa Catarina. E-mail: markantfilos@yahoo.com.br.
} 


\section{INTRODUCTION}

The question that we propose to treat is vital in ethical theories that have emerged in the West during the Middle Ages and Modernity, but also is central in the ethical-political contemporary thought, namely, the pursuit of autonomy and liberty exactly human. It is true that in areas apparently as distinct or even unrelated, it is imperative to establish a lead that can justify the date of such constructions. Given this, we have established the concept of desire and their ethical-political developments, as the gauge that can put on-line search of such values in different historical periods. The developments to which we refer are the theoretical implications, both as political ethics constitute basic form the anchorage of political aspects since the end of modernity to contemporaneity.

As a result of the influence of these developments we noticed the predominance of an ethical-political formalism which highlights the conceptualization of human freedom and of their political and social traits. The construction of this scenario the will, and its consequences, cannot be restricted to the binary Contemporary-Modernity, we must understand that the concept of will is in slow emergence from the late Antiquity and early middle ages.

\footnotetext{
The will is a notion that the founders of ancient philosophy ignore. She will make your real appearance in stoicism and only reach a central position in a thought inspired and determined by religion. Velle, voluntas, become a dominant theme in the thought of Augustine. The Scholastics systems will develop the conceptual structure of the concept, and is in the modern Christian inspired philosophies that she can turn on to your almost definitive formulation. (VETÖ, 2005, p. 11).
}

However, it is obviously foolhardy bring halt here dialogue with all authors who participated, directly or indirectly, of the construction of this huge philosophical concept. By prudence in view of this it is impossible we will take our research field in the works of two giants of Western ethical thought, namely, St. Augustine and Immanuel Kant. This intellectual movement is only possible if we elect the ideas of autonomy and liberty as assumptions that make up the concept of will. When we say assumptions, we are certainly setting points, within the broader theory, are pillars of the building of the concept.

We can identify these assumptions passing both in the lanes of ethics as the avenues of politics. The ideas of autonomy and liberty are part of the conceptual core of most political 
Artigo: Autonomy and liberty in Augustine and Kant: the predominance of the formalism in the concept of will

and ethical theories, mainly from the modernity. Such assumptions are visceral in the Augustinian constructions and the Kantian concept of will, being related to each other, both assumptions merging as the product of an actual human essence.

The terms that make these assumptions of autonomy and liberty are being established at the end of antiquity and still erupt throughout the Middle Ages, leveraged by the Augustinian impulse, and in the Modernity, taking in Kant your more robust and adapted format to rational laws stipulated by an uncompromising Enlightenment. However, even having new clothes on her shoulders, such assumptions carry in their bowels a dualism that characterizes both the constitution of the will while concept as their developments in the ethical and political spheres. We are treating the dualism between materiality and formality of the action. Simple terms that carry the weight of numerous philosophical concepts and disputes between strands of thought from various schools and historical periods. For this range of load related assignments to these two terms, material and formal, you must establish the boundaries that keep us on the theme proposed and in the statement that we intend to implement.

From this point, having ranked even that brief the hotpots of our enterprise, we can settle our itinerary. Our goal is to demonstrate how the concept of will in both Augustine and Kant carries the catalyst of a predominance of ethical formalism on the materiality of the action. The center of the Constitution of this concept consists of the assumptions of autonomy and liberty, these terms always were present in discussions about ethics and politics since antiquity. In this way, we will present first the way how the ideas of autonomy and liberty have been bastions of support of the concept. Having completed this explanation, we focus on the Augustinian construction of the concept of will, seeking to highlight its intricacies that evoke in man your essence of liberty.

This move will allow us to see the theoretical skeleton upon which the concept of will take body and volume. However, we will still realize that the evolution of the ideas of autonomy and liberty needed to follow a path toward the man himself. From the Kantian scope will be possible to demonstrate, according to our proposal, the debugging suffered by the concept of will of all metaphysical and theological waste which imposed such a theory from your foundation.

However, we also hope to demonstrate that the core of the concept of Will, established in its assumptions already listed, remains intact in the Kantian construction, keeping the 
imbalance between dualistic terms of materiality and formality, both present in Augustine. That is, the same quest for autonomy and liberty that leveraged the emergence and the development of the concept of will, in their metaphysical and theological bases in the Augustinian medieval period, continues latent in the Kantian thought by linking the existence of such presuppositions to the clash between materiality and the formality that permeates the ethical action in adherence to the moral law. "It is therefore the mere compliance with the law in general which is the principle of goodwill; and that's what is the Kantian formalism". (PASCAL, 2003, p. 115-116.).

At the end of this study, we intend to have demonstrated, even if succinctly, that the Augustinian and Kantian constructions of the concept of will follows a historicalphilosophical track that was engaged in the pursuit of ideas of autonomy and liberty of the individual human, having your beginning still in the medieval period and extending, through its consequences, until contemporary times.

\section{THE EMERGENCE OF THE WILL AND ITS ASSUMPTIONS}

The term 'will' has numerous connotations in the history of Western philosophical thought, as well as in the development of modern psychological and psychiatric sciences. However, the character of the concept of will to which we are seeking in this work is clear and was being drawn in a compact and robust way. It must be understood that it arises first as the attempt to assure the human individual its main characteristic, the liberty. This liberty is undoubtedly a value that comes out, in the Christian tradition, from the political ties that involved the individual. However, in ancient traditions, especially Greek, liberty is a value attached indelibly to the political sphere, in a way that was an impediment to think of such liberty as something coming only from an ethical-moral update of individuals separately.

Thus, the concept of will was being framed, at the beginning of the medieval period, under the auspices of a big breakup between cultural paradigms that establishing its assumptions of freedom and ethical-political action, especially that of classical Rome. As indicated by Brown:

One aspect of late-Roman society-often more evident to the medievalist than to the scholar of the classical world - is the slow emergence of a society always outlines 
Artigo: Autonomy and liberty in Augustine and Kant: the predominance of the formalism in the concept of will

more clearly defined by religious creed. The heretic, the Hebrew and the pagan become second-class citizens. (BROWN, 1975, p. 7).

This is extremely important to understand the emergence of the concept of will as something dependent on a whole rearranging of political, ethical and religious understandings about human being. As we said, in the ancient Greek and Roman traditions especially, the liberty of the individual is an intrinsic value to political life, this being in your turn the composition of an entire religious and moral arrangement, with various standards and conceptions about the individual.

In the Greek philosophical tradition emerged influential conceptions of man about your ethical action. One of the most important is without doubt the Socratic-Platonic intellectualism, in it is contained the understanding that the individual only makes evil by not knowing what is good. It is postulated in this case the existence of a cognitive instance which features a simple feature discernment between good or bad, that is, the individual recognizes between two options the one that guarantees the good and never the opposite way.

Surely the mere intellectualism is not a theory of the will, there is the simple observation that the individual needs to recognize primarily good, to do so. The bad action would only be made involuntarily, without being able to be had as a choice, being taken only as the result of an act of ignorance, making fault something irresponsible, which becomes problematic in a theory of the will. We say problematic because the idea of liberty carries with it the idea of guilt, that is, if the individual is free to choose something he assumes full responsibility for his actions. In this sense the individual cannot be excused by the claim of not knowing what is right or just follow what is the guideline your cultural society. In the mold of an incipient notion of will the liberty of action of the individual carries the blame not only for the actions carried out, but even the intention involved in choice of action.

The first step to shape the idea of liability of the individual is given by the insertion of the wishes on how the trial account of the actions or intentions of individuals. This step undertaken by Aristotle in your ethics of virtue, individuals can neglect the well in view of your wishes that are contrary to this well. The individual can know what is right, to be able to do it, but, by weakness of deliberation and of his habits, he commits what is wrong by force of his desires misrepresented. The desire of evil, or the possibility to accept the desire of what is harmful and damaging, points to the existence of a failure attributable to the individual, a 
failure of choice, not out of ignorance, but, because there is in the individual a conflict between desires. That is, even after finding the existence of a good and an evil, the individual opts for the evil, characterizing an akrasia, not out of ignorance, but out of weakness.

However, the individual is still held as a passive prisoner of a simple choice, either hanging on to the good and the just or indulging in the rashness of his sensitive desires. There is still no perception of a want to be detached from these bonds. From this focus it is obvious the claim of an instance that elevates the individual to a condition of freedom, not only cognitively dependent on the knowledge of good and evil, and not only taken by conflicting desires from their capacity desiderative. However, such an instance must be rooted in the individual himself, paradoxically, for this it is necessary to think of a universalization that can encompass all human beings, regardless of culture or nationality.

In both Augustine and Kant, this universalization will be anchored in a legislative body, that is, through the contribution of a moral law that can be recognized and accepted by any individual rationally. Those two perspectives, both intellectual and desiderative, remain somewhat linked to cultural ties that value what is good and evil, right and wrong, and are still attached to the realm of ends. The man is a being divided between the steamroller of cultural norms and the avalanche of contradictory desires that drive your choices.

There is no doubt that this picture seems to show an extreme incapacity of man to avoid predetermined choices, either by the weight of the customs or by the harassment of the desires, all aiming at an end that already seems determined. And this is precisely the perspective that will become prominent in the defense of the search for an instance that allows man to be free in both cases, both the cultural ties and the bonds of sensitive desires and their ends. "The will will be thematized when the attention is centralized in the action of the subject in itself, independently of the results and the eventual consequences of this action". (VETÖ, 2005 , p. 12.). However, as we said above, this movement occurs in a scenario in which cultural ties are weakened in all its spheres, politically, socially and mainly religious.

Thus, the individual's dependence on cultural ties is broken when the civilization paradigm under which he is inserted undergoes extreme rupture. This is indicated by the change in the relation between individual and society, the way in which the nature of the individual is conceived and its role in the world and in society, mainly given the overlap of a new paradigm over the old one. We can sense that this was exactly the case in the period in which the concept of will begins to be developed. The end of classical Antiquity brought with 
Artigo: Autonomy and liberty in Augustine and Kant: the predominance of the formalism in the concept of will

it the extreme rupture between deep cultural ties and a deep split in the civilization paradigm that marked this historical period.

Certainly we are not treating only with political-historical factors, but rather we seek to make clear the thesis that the concept of will arises precisely at the moment when a profound civilizational change takes place within Western culture. In this profound change are included a new way of understanding human essence and political relations between individual and society. We can not, however, attribute this exceptional event to only one factor, we can list the main ones, the decline of ancient empires, the fragmentation of European peoples and emergence of a religion detached from the cultural roots of a single people. For Labriolle (1942, p. 13): "Devotion without limits to the state, taste for honors, respect for established worship, whatever the intrinsic truth, love of comfort, pride of life, none of these constitutive values of ancient civilization compromises the Christian spirit...".

Given this scenario, we can understand that liberty in the political sense is understood as a freedom in the individual sense, that is, with the change of the old civilizational paradigm individuals are not only extensions of their societies. In this way, the ethical liberty to be sought is not that prey to the cultural customs of a people, on the contrary, it means the individualization of the subject in relation to these same customs. In the religious field, liberty becomes a gift provided by the very essence of man, since the new emerging religion, Christianity, understands the individual in personal terms and detached from the worldly context of both society and desires.

Certainly in Modernity the central motive of the will will not be the metaphysicaltheological basis brought about by Christianity in the early Middle Ages. Under the wings of the Enlightenment, the liberty and autonomy of the individual, especially in the sphere of morality, will be erected on the firm foundations of reason. Thus, the metaphysical basis of the will gives way to a purely rational basis, having as its main support the assumptions of autonomy and liberty. However, the universalizing character of the will will still be one of its main bases, and still the idea of a universal moral law will be present in this construction. Even if not thought in the mold of a theological moral law, the moral law in modern construction will be a guarantee to demonstrate the rational and moral freedom of the individual. 


\section{THE FREE WILL IN AUGUSTINE}

The theme of liberty in the individual sphere, as we have tried to present in the previous point, has taken on an ethical-political sense from the split of the civilizational paradigm of the end of the Old Age and beginning of the Middle Ages. The terms that are based are those of an individual justification of the subject agent, both ethically and politically, from bases that allow a liberty independent of cultural, traditional or desires. We can think that the question starts from a metaphysical-theological approach, obviously the main discussion present in Christian production is the transcendence of man in his spiritual nature, permeated by the immanence of the divine present in the truth of the existence of a hierarchy not only natural or physical, but rather transcendent in relation to earthly existence.

In Augustine the will will be thematized from its most formal bases, having obviously, as we shall indicate, a strong trajectory, basically theological, but also influenced by constructions from Stoicism. In addition, Augustine is part of the period of civilization split that we have alluded to earlier. His quarrels against the pagans led him to write his masterpiece, The City of God, and to compose most of his theological work. In view of this, it is correct to say that one of the reasons why Augustine sets out to think about the autonomy and liberty of the individual is the need to justify such presuppositions on theological but also political grounds. Second Brown (1975, p. 19): "The central problem of Augustinian thought is a problem that we are all called upon to face: what extent is it possible to consider man capable of exercising a form of rational control over his political environment?"

The ontological-cosmological factor present in the conceptualization of intention from Stoic $^{1}$ thought will be transmuted into a metaphysics of the will, a quest for justification of man's moral action from his spiritual reality. This construction will have as its guiding thread the inner conflict of the will, a duality that is based on the search for the distinction between what is spiritual and what is natural. This inner struggle, according to Augustine, will have its arena mounted on the moral action expressed in the choice:

1 Certainly stoicism is the first movement of internalization of the moral value of the intentions of the agent individual, its total refusal to impose external agents will provide the basis for establishing an internalized and autonomous will. First as a movement of total subjective interiorization of will, as we noted in Seneca (19--, XIV, 50): "It is finally necessary that our soul, renouncing all external benefits, withdraws entirely in itself: that it only relies on itself and only rejoices with it, that it only enjoy its own goods, that it withdraws as much as possible from strangers and consecrate herself to herself, that the material losses make her insensible and that she even finds a good side in her misfortunes".

Sapere aude - Belo Horizonte, v. 11 - n. 21, p. 173-193, Jan./Jun. 2020 - ISSN: 2177-6342 
Now lust arises out of perverse will; while lust is used to contract; and if you do not resist a habit, a need arises. This was how, through a kind of intertwined ring - that is why I called it a chain - it held me tight in hard slavery. The new will, which began to exist in me, the will of honoring you gratuitously and of wanting to enjoy you, Oh my god, only safe contentment, was not yet able to overcome the other will, fortified by concupiscence. Thus two wills, one concupiscent, one dominated, one fleshly and one spiritual, each fought in me. Disagreeing, they teared my soul. (AUGUSTINE, Confessions. VIII 5, 10. 19--).

The necessity of establishing an autonomy of the individual in relation to the perturbations of destiny, or of the inevitable natural order, which made the Stoic a wise man capable of complete freedom through the interiorisation of his moral intention, yields place to the search for the detachment of the physical nature which shackles the man in a will submitted to the impositions of the physical world. In Augustine's extensive work the will emerges as an intention purified by the spiritual reality that supplies the want of the carnal nature, or physical, which by the unruly habit annuls the soul's will. Second yet Augustine: "Therefore, it is no prodigy in part wanting and partly not wanting, but soul sickness. In fact, this one, overwhelmed by habit, does not rise fully, although it is helped by the truth". (VIII 9, 21). From this angle one can see the dispute between two types of will, in the most intimate of man, with apparently harmful implications if good will does not win.

Still thinking of the basis of Stoicism, the sage understood the hierarchy of the natural reality, understanding it as inevitable and itself subject to this ordering, and precisely because of this his consent, while wanting unison with this inevitability, made him free. In a certain way, this basis is presented in several aspects in the production of Augustine, since we find a complete hierarchy, between the material and the spiritual, being that such order is established by God and includes man himself, and his consent with this order harmonizes it with the will of God. "In any case, St. Augustine's answer is radical: there is no other cause of sin than the unregulated will, the improba voluntas." (CAPITANI, 1994, p. 163).

Certainly it is necessary to make it very clear that the understanding of the moral configuration of both is distinct, in Stoicism human nature is endowed with reason and therefore capable of knowing and accepting the natural order of reality unavoidable, consenting to it and being free in their intention. In Augustine, man absorbs in his action the divine will, not only submitting to it, but accepting it, not consenting with this divine will is only the result of a bad will of man, fruit of his vicious and sinner nature. As Gilson argues: 
Nature is necessarily governed by that order, which God imposed upon it, and man, insofar as he is a part of nature, submits to the divine order without being able to withdraw from it. On the contrary, a capital difference appears with actions that depend on the human will; instead of necessarily being governed by the divine order, these actions have as their object to realize it. Here, it is no longer a matter of submitting to the law, but of wanting it and collaborating with it. The man knows the rule; the question is whether he wants it. Consequently, everything depends on the decision that man takes or does not take, to reign in himself the order that he sees imposed by God on nature. [...] The force that such an important decision depends on is just the will. (GILSON, 2006, p. 252).

In view of this scenario it is necessary to understand that such an arrangement follows the ordering of a legislation imputed to both man and nature, in man acts the moral law receiving the divine emanation, in nature acts the law of ordination given by the Creator himself. "God is therefore the sovereign legislator. His reason has conceived the order of the world; his will accomplishes it; his providence preserves it." (COMBES, 1927, p. 128). By this arrangement is opened the possibility of thinking of a free will, that is, the freedom that the individual has to accept or not the ordination that emanates from the divine source and that feeds it through the moral law. In the words of Saranyana (2006, p. 85):

The Augustine's answer is clear: the human will, considered in itself, is good, and free will, in itself, is a good and condition for attaining happiness; however, the created will is fallible, it can be mistaken, and the exercise of free will carries with it the risk of sin. In this way, free will becomes evil when it is deprived of due order.

Although slightly distinct in some correlated points, the core of the two views is on the same level, moral discussion is not in the field of simple materiality. The Stoic consent to the order of natural reality and its freedom expressed in intention, as well as the acceptance of the divine order of nature and the want of the will adjusted to the divine will in Augustine, throw man out of the simple deterministic nature. Thus, in both man has something in him that escapes the simple deterministic condition, something that makes it unique, free. Second Vetö (2005, p. 46)., "the recognition of the essential non-naturality of the will allows Augustine to establish the beacons of a non-material morality in which matter, the content of action, still does not prejudge its moral reach."

This characteristic has already been pointed out in Stoicism in its conception of intention, but in Augustine the will is taken as good in its harmonization with the will of God, an overcoming of ontological metaphysics by theology, something that in his work is strongly marked. In a way, this Augustinian vision of a theocentric will brings a strangeness front the 
Artigo: Autonomy and liberty in Augustine and Kant: the predominance of the formalism in the concept of will

notions of virtue and good, originating from non-Christian (pagan) civilizations, since any virtue that is not agreed with the divine will and love of God, even if it produces momentary happiness, can not be considered as good. In Boyer's opinion (1920, p. 223):

\footnotetext{
Our author states that the sovereign good is God and that our happiness consists in owning God. The proof is this: we are able to know and love God: from then on God is the supreme object and the natural end of our activity, the end of our being. This is what St. Augustine presents, in a very simple but already formed plan as to the essential characteristics in his works....
}

This restricted perception is decisive in the Augustinian thesis, since it launches the autonomy of a will, which is only endowed by an intention liberated by divine grace. Free from the bonds of human fragility induced by the desire of material things, but articulated according to the good conduct of the divine will. At this point there is something that we can point to as the orientation towards a universalization that directs the determination of good will or good intention. In these terms, it is unthinkable that a sage becomes virtuous only by his own intellectual qualities, or by his austere customs, the need arises for a universal condition of a regulatory framework of the will. In these terms, it is unthinkable that a sage becomes virtuous only by his own intellectual qualities, or by his austere customs, the need arises for a universal condition of a regulatory framework of the will.

It is clear that it is not enough to have virtuous customs, habits are naturally addicted to our contradictory nature, it is not enough to have a good intention, it must reflect the divine will, be according to the will of God, and it is not enough to have free will must be directed by the eternal divine law, given to man through his moral conscience. Thus, Augustine elaborates on the old concept of intention present in Stoicism, and yet it launches bases, even if incipient, for an understanding aimed at the inevitably universalizing moral autonomy present in man from his moral conscience.

The strong distinction between the formal content and the material of moral action will continue to be present in the ethical discussion pursued in the intellectual production of Christianity and modern philosophy. In general terms, the autonomy of the individual occurs in the political and natural spheres, however, not depending on these spheres to update their condition of liberty, that is, a detachment of the obstacles that condition morally. In the same sense, liberty is possible from the adhesion, through free will, to good will, that is, the will guided by the moral law enlightened by the divine will. 
As already mentioned, these terms of autonomy and liberty through the will will be discussed more deeply in Modernity, especially as regards the detachment of reason as a source of terms. No longer will the metaphysical-theological basis be used to ground autonomy and liberty of will in view of moral law. In this movement no one will be more successful than Immanuel Kant in his critique of morals, his theoretical construction will be strongly directed by the Enlightenment ideals of valorization of reason and its legislative autonomy.

\section{AUTONOMY AND FREEDOM IN THE FORMALISM OF THE WILL IN KANT}

Put these first traces of the will in the Middle Ages from Augustine, even if succinctly and synthetically, we will follow our argument based on the search for autonomous will in modernity, more specifically on the gigantic work of Immanuel Kant, where the formalism, autonomy and liberty of the will find refuge in a theory that guarantees security and plenty of ammunition. There is no doubt that Kantian theorization marks with strong features its formal inclination through the intention to establish purely rational bases in the ethical discussion of the foundation of the will.

Kant proceeds in his argumentation taking as central base the practical reason, responsible for giving us the guidance in the execution of our actions. "The first task for the second Critique, then, is to show that the 'reality' of the 'concept of freedom' is proved by an 'apodictic law of practical reason,' that is, the moral law itself." (GUYER, 2006, p. 211). The Kantian construction of the will, even if rationally anchored, still reveals a metaphysical bias centered on pure intentionality, not in a derogatory sense, but in the sense of maintaining the distinction between formal and material, especially in the sense of being impervious to any external influence. For Vetö (2005, p. 204):

Kant, as we know, regards will as the highest reality in the world. The value of the will corresponds to the purity of its intention; Now, the moral purity of intention is deduced from its metaphysical purity. [...]. The moral scope of the will corresponds to its independence from any external, heteronomous moral mover, but the moral autonomy of the will comes from its metaphysical autonomy. Kant wonders about what a pure will is, about what a good will is, and behind that question, the conclusion is almost outlined: will as such, will, which is only will, is goodwill. 
Even in the face of this realization, we can say that Kantian sophistication will be more clearly demonstrated in the intransigent defense of a purely rational will, a good will governed by its own will, and is therefore shielded from the heteronomy of natural causality. "Good will is the willingness to give itself the law of its action independently of every sensible motive, wanting nothing more than the pure form of its own legislation." (VAYSSE, 1998, p. 61). This upward movement out of the realm of the heteronomy of nature reveals its concern not to fail to expose the radical spontaneity of reason expressed in the freedom of the will. It will be somewhat paradoxical to realize that in Kant liberty is given through the promulgation of duty, and thus, duty directs the maxim of want, it is the spontaneous liberty of reason in the objectification of the moral law. "The whole breadth of Kant's reasoning is summed up in this celebrated formula: 'You may because you must'. (Du kannst, denn du sollst).” (BENDA, 1961, p. 38). This mechanics is essential for the definition of good will as an autonomous expression of practical reason that establishes its own principles in law enforcement. For Kant (2000, 5:29):

But if no determining ground of the will other than that universal lawgiving form can serve as a law for it, such a will must be thought as altogether independent of the natural law of appearances in their relations to one another, namely the law of causality. But such independence is called freedom in the strictest, that is, in the transcendental, sense. Therefore, a will for which the mere lawgiving form of a maxim can alone serve as a law is a free will.

The liberty of the will is based on its own laws, it is the maximum expression of the autonomy, since such laws are not determined by its ends, but by practical principles. Such liberty is proved by the law of practical reason, but is in itself an a priori idea of speculative reason. As follow: "But among all the ideas of speculative reason freedom is also the only one the possibility of which we know a priori, though without having insight into it, because it is the condition of the moral law, which we do know." (2000, 5:4).

This determination of the spontaneous liberty of the will from self-legislation will be crucial in defining the moral feature of Kantian theory, especially in its claim to universality. The quest for this universality in view of the spontaneity of practical reason is the basis for the distinction of practical principles from the subjective and objective conditions between the maxim and the practical law. As follow: 
Practical principles are propositions that contain a general determination of the will, having under it several practical rules. They are subjective, or maxims, when the condition is regarded by the subject as holding only for his will; but they are objective, or practical laws, when the condition is recognized as objective, that is, as holding for the will of every rational being. (2000, 5:19).

In this way, the distance between the actions and the principles that impel them is increased, the will giving itself its laws expresses in its maxims its liberty and autonomy, nothing but its own principles can be its motivation, if not, it will be a limited action of the faculty to desire not directed by the liberty of practical reason. In Deleuze's view (1963, p. 42):

Still the concept of liberty, like that of noumenon, would be purely problematic and indeterminate if reason had no other interest than its own speculative interest. We have seen that only practical reason determines the concept of liberty by giving it an objective reality. In fact, when the moral law is the law of the will, it is wholly independent of the natural conditions and the sensitivity that binds all cause to an earlier cause...

This point is crucial to differentiate the understanding brought by Kant in view of the other previous postulates of liberty of will. It is not only the moral valorization of intention, as in Stoicism, nor the just agreement of this intention with a supreme good expressed in the divine will, as in Augustine, but rather it is the capacity of self-legislation of the rational being as a promulgator of its own principles that gives the autonomy of the will.

The autonomy of the will is not represented by mere indifference to external things, it goes further, it is liberty to give itself its laws by its own principles. This movement is radical and exactly aims to give the mark of its self-legislative character to the will. Kant wants practical reason to be the source of the self-legislation of the rational being, since this reason alone is capable of determining a will, being a foundation contained in pure reason. Second Kant (2000, 5:20): "If it is assumed that pure reason can contain within itself a practical ground, that is, one sufficient to determine the will, then there are practical laws; otherwise all practical principles will be mere maxims".

"The man, by virtue of his nature, is not only a being endowed with reason." (KRÜGER, 1961, p. 101). A purely rational being would act only according to its reason, its will would not risk being tainted by the intervention of a heteronomous external entity represented by empirical desires. But man, even being a rational being, is not a pure being, he 
still suffers with his empirical desires when it comes to forging his will. For Guyer (2006, p. 179-80)

The fundamental principle of morality, Kant has claimed, must be unconditionally valid for any rational being. If any being were perfectly rational, it would automatically act in accordance with this law, and the law would therefore not appear to be a constraint. But we human beings are not perfectly rational, and thus although we recognize the unconditional validity of the moral law, it also appears as a constraint to us, something that may be in conflict with our irrational side.

There arises the point of tension that will give Kant's philosophy its characteristic feature, since it is not only rational, man needs a universal point of the will. This point is properly in the practical reason, to be rational is to establish, front its spontaneity in the representation of the objects, a principle that guides the maxims, namely, the duty, as previously mentioned, since the maxims is a subjective principle of the practical action. Second Engstrom (2010, p. 33):

As rational, it is knowledge in which the predicate's attachment is derived from a principle, or representation of a law, to which the subject subordinates itself. It is thus an act of cognitive self-determination from a principle: one's determination, derived from a principle, of what one ought to do.

The rule of the practical action of the maxim must be constituted in a rational way, since it is subject to the individual's faculty of desire. Therefore, the rule of practical action prescribed in the maxim must be an imperative, a rule established by duty. In the words of Kant (2000, 5:20) himself:

\footnotetext{
A practical rule is always a product of reason because it prescribes action as a means to an effect, which is its purpose. But for a being in whom reason quite alone is not the determining ground of the will, this rule is an imperative, that is, a rule indicated by an 'ought', which expresses objective necessary to the action and signifies that if reason completely determined the will the action would without fail take place in accordance with this rule. Imperatives, therefore, hold objectively and are quite distinct from maxims, which are subjective principles.
}

Postulating the centrality of objective principles, Kant establishes the universalization of duty in the figure of the imperative, given as a universal mode for the objectification of maxims according to the moral law. The imperative is the guideline according to which the maxim must respond, while at the same time it indicates the path of universalization, it also 
induces reflection, making the analysis of the maxim a task of analysis of the founding principles of the will contained in it.

However, it is still necessary to understand the establishment of this imperative in relation to the complete universalization of duty, the complete overcoming of dependence on the heteronomy of nature and the products themselves of the simple faculty of desire of the individual, influenced by feelings and happiness. In this broad movement of establishment of the complete universalization of duty Kant distinguishes two types of imperatives.

The differentiation occurs within the maxim of action, the hypothetical imperative gives reason an action as indispensable for the realization of a certain end, while the categorical imperative proposes an action as indispensable in itself, unconditionally. Second Kant:

\footnotetext{
Now, all imperatives command either hypothetically or categorically. The former represent the practical necessity of a possible action as a means to achieving something eles that one wills (or that it is at least possible for one to will). The categorical imperative would be that which represented an action as objectively necessary of itself, without reference to another end. (KANT, 2000, 4: 414).
}

The categorical imperative indicates, therefore, to act for duty, purely and simply, not relating the maxim to some interference of the simple desired end, be it subjective or objective. It is the expression of pure reason in its practical foundation, and it is necessary to understand that this determination relates to the purity of the will, regardless of the material intricacies of its execution.

The empirical data of the moral action are determined in the maxim, from the intention of the individual to establish its target, being therefore achievable according to its possibilities, as well as in the hypothetical imperative, however, the formalization of moral action determined in the categorical imperative is pure in the sense of not being attached to empirical establishments, being valid for its universalization. This distinction is responsible for the definition of the condition of law of the categorical imperative, since the maxim can suffer external conditioning of the collimated ends, just as the hypothetical imperative is subject to conditioning of achievement, the factor of necessity contained in the categorical imperative gives it the condition of law, as opposed to the contingency contained in the maxim and the categorical imperative.

This distinction is responsible for the definition of the condition of law of the categorical imperative, since the maxim can suffer external conditioning of the sought ends, 
Artigo: Autonomy and liberty in Augustine and Kant: the predominance of the formalism in the concept of will

just as the hypothetical imperative is subject to conditioning of achievement, the factor of necessity contained in the categorical imperative gives it the condition of law, as opposed to the contingency contained in the maxim of the hypothetical imperative. While law the categorical imperative represents the universality of the will in the independence of its pure necessity, exempt from the alternations of empirical and subjective influences.

The moral subject who follows this imperative, this law, is acting in a way to accept the formalism expressed in its universality, the freedom to adhere to a law given by itself according to a law accepted by itself. "The simple form of the law can not therefore come if no from a non-sensitive faculty that transcends simultaneously all phenomena and their principles of causality." (HÖFFE, 1993, p. 131).

Such a faculty is certainly the pure practical reason expressed in the categorical imperative. This factor gives its condition of transcendentality, the liberty expressed in the unconditional formalism of the universalized moral law in the imperative is absolute because it is totally established by rational principles, not attached to empirically apprehended heteronomous entities. The transcendental moral subject is that which, in its moral action, uses pure reason in its practical foundation, and imposes its action on the sensible world, yet without starting from it as a principle for such action, having as its guideline the categorical imperative as regulator of the principles of his maxims. Still for Höffe (1993, p. 132):

\footnotetext{
With transcendental freedom, the principle of morality no longer resides as in Aristotle in a supreme (insurmountable) end, in happiness. The morality takes its source in the absolutely first principle, the unconditioned principle of establishment of ends; the principle of morality lies in the establishment of the ends by itself. In this Kantian perspective, the idea of the responsibility of human action is all its acuity and its radicality, namely, the quality of transcendental freedom or the autonomy of the will.
}

The reality of liberty and autonomy of the will lies not only in its total detachment in the intentionality of will, but rather in the promulgation of a principle which is not given by any external entity to the very reason of the moral agent. The transcendentality of the liberty of the will from practical reason establishes the self-legislative character of the moral autonomy of man. A universality that guarantees the primacy of reason over natural inclination, a state of complete independence from the natural determinism of empirical desires, and in this way we can argue that in Kant reason ascends to its condition of absolute autonomy, especially in its foundation practice of moral action in the sensitive world. 


\section{CONCLUSION}

The slow construction of the definition of the autonomy of the will occurred from the separation, or rather, distinction between the material action and the formal intention. In this way, the idea of intention, free from the inevitable determinism of natural processes, gave man the possibility of wanting beyond what was physically determined by the natural ordering of the world around him. In the Christianity this notion was enlarged and received the character of will expressed as a condition of overcoming the very finite nature of man. The idea of a will aligned with the will of God brought to man the condition of escaping the finitude expressed in the limitation of his carnal desires, dependent on the deterministic realization of his needs.

In terms of a will thus established, it was not enough to have an intention free of natural determinism. It had to be a disinterested intention, existing by itself in view of its purity. The autonomous liberty of man is complete only when established by himself, so it is necessary to think of a will that is given by itself, not only free of natural determinism, not only expressed in the reality of intention, even if disinterested. It is imperative that it be a selflegislating will, within which its want is the fruit of universal conformity with a law given to itself from itself.

What we see is the promulgation of an autonomous, free, self-legislating will capable of ensuring the realization of the purest human action. In this way, the theory of the will receives in its finished version the condition of maximum expression of the abstraction capacity of human reason. It, thrown upon itself, may stand front the world as the author of its own law. This allows us to say that the whole linear course of his history has traced the untiring search for a separation, a differentiation that would guarantee man his position of prominence, free in his own rational condition.

All this long and intricate process was permeated by untiring searches for a solid systematization and very well grounded in philosophical foundations. However, all the correlating factors that influenced it, such as culture, religion, and even the political systems through which it has passed, can not be excluded from this process. Still in the Christian context, represented by Augustine, we perceive that the new instance of the will bestows on man a source of openness to what should be the guiding point of the right to want. In 
Artigo: Autonomy and liberty in Augustine and Kant: the predominance of the formalism in the concept of will

Augustine, the will appears as a power of the soul that is regulated by divine grace, harmonizing with the will of God that illuminates the moral conscience of man.

The will of man as free will is good in itself, but only well exercised insofar as it is guided by this divine action. Only if it is the result of love of the law of God, but if it arises only in the will of man himself, it will be weak. On another level, Kantian thought is built on bases built from the materials provided by Enlightenment, German idealism, and the incipient maturation of the physical sciences in Modernity. The centrality of reason as the supreme systematic source of knowledge and human action gains a strong feature in the thought of this author.

In Kantian thought intentionality still has primacy over the end of action itself, but its concern is not to leave man at the mercy of his sensitive inclinations and to give him the weapons of pure practical reason. The autonomy of the will remains as distinct from the sensible level. However, the divine element becomes only a postulate and reason assumes the supreme enactment of the autonomy of this will. It is possible to understand that Kant's intention is not to give substance to the instance of the will, as if from his own desires or the determination of some divine entity.

The liberty of the will consists in the self-determination of pure practical reason in its formal autonomy. The will does not appear as an instance grafted on man in order to guarantee an independence from his empirically conditioned nature. This reality is established by reason itself in its autonomy in relation to any external factor that can determine it. The liberty is constituted as a condition for will. Such liberty is inscribed solely and exclusively within the rational sphere.

Finally, we understand that this upward movement of the will, out of the heteronomous world of the ends of action, leads to a change in the political and ethical paradigm in the West. The various theoretical understandings that will come from this influential conception of man will always be directed to conditioning the concrete action of the individual in the postulation of principles, be they legal, moral or philosophical. Thus, there is a supremacy of the conceptual formality of action on the very end of acting. It is certain that the Illuminist republican thought, based on the idea of supremacy of the rational legislation of the body politic will be a clear expression of this movement. Several aspects of a democracy based on the search for concepts of justice, equity, conceptions of individual freedom of man will also be reflections of this movement initiated by the search for autonomy 
and liberty in the theory of the will. A movement of overvaluation of principles to the detriment of simple and materially determined goals.

\section{REFERENCES}

AUGuStine. The Confessions of St. Augustine. Translated by J. G. Pilkington, M . A. New York: International Collectors Library, [19--].

BENDA, Julien. O pensamento vivo de Kant. Tradução de Wilson Veloso. São Paulo: Livraria Martins, 1961.

BOYER, Charles. L'idée de vérité dans la philosophie de Saint Augustin. Paris: Gabriel Beauchesne, 1920.

BROWN, Peter. Religione e società nell'età di Sant'Agostino. Torino: Giulio Einaudi Editore, 1975.

CAPITANI, Franco de. Il "De Libero Arbitrio" di S. Agostino: studio introduttivo, testo, traduzione e commento. Milano: Vita e Pensiero, 1994.

COMBES, Gustave. La doctrine politique de Saint Augustin. Paris: Librairie Plon, 1927.

DELEUZE, Gilles. La philosophie critique de Kant: doctrine des facultés. Paris: Presses Universitaires de France, 1963.

ENGSTROM, Stephen. Reason, desire, and the will. In: DENIS, Lara (ed.). Kant's

Metaphysics of Morals: a critical guide. Cambridge: Cambridge University Press, 2010.

GILSON, Étienne. Introdução ao estudo de Santo Agostinho. Tradução de Cristiane Negreiros Abbud Ayoub. São Paulo: Discurso Editorial; Paulus. 2006.

GUYER, Paul. Kant. New York: Routledge, 2006.

HÖFFE, Otfried. Introduction à la philosophie pratique de Kant: la morale, le droit et la religion. 2. ed. Paris: J. Vrin, 1993.

KANT, Immanuel. Critique of pure reason. Translated and edited by Paul Guyer and Allen W. Wood. New York: Cambridge University Press, 2000. (The Cambridge edition of the works of Immanuel Kant).

KANT, Immanuel. Practical philosophy. Translated and edited by Mary J. Gregor and Allen Wood. New York: Cambridge University Press, 1996. (The Cambridge edition of the works of Immanuel Kant).

KRÜGER, Gerhard. Critique et morale chez Kant. Tradução de M. Regnier. Paris: Beauchesne et ses fils, 1961. 
Artigo: Autonomy and liberty in Augustine and Kant: the predominance of the formalism in the concept of will

LABRIOLLE, Pierre de. La réaction païenne: étude sur la polémique antichrétienne du I au VI siécle. Paris: L'Artisan du Livre, 1942.

PASCAL, Georges. O pensamento de Kant. Introdução e tradução de Raimundo Vier. 8. ed. Petrópolis: Vozes, 2003.

SARANYANA, Josep-Ignasi. A filosofia medieval: das origens patrísticas à escolástica barroca. Tradução de Fernando Salles. São Paulo: Instituto Brasileiro de Filosofia e Ciência "Raimundo Lúlio", 2006.

SÊNECA. Obras: Da tranquilidade da alma. Tradução de G. D. Leoni. São Paulo: Atena, [19--].

VAYSSE, Jean-Marie. Le vocabulaire de Kant. Paris: Ellipses, 1998.

VETÖ, Miklos. O nascimento da vontade. Tradução de Álvaro Lorencini. São Leopoldo: Unisinos, 2005. 